\title{
Assessment on Accumulation of Heavy Metals and its Effect on Liver Tissues of Harpodon Nehereus from Mumbai Coast of Maharashtra, India
}

\author{
Archana 0za', Leena Muralidharan² \\ ${ }^{1}$ Research Scholar, ${ }^{2}$ Research Guide \\ 1Department of Zoology, Ramniranjan Jhunjhunwala College, Mumbai, Maharashtra, India \\ ${ }^{2}$ Department of Zoology, V. K. Krishna Menon College, Mumbai, Maharashtra, India
}

\begin{abstract}
Heavy metal pollution is a very serious issue in the present world and is caused by release of toxic substances from industrial and domestic sources into the sea water leading to harm marine organisms. Marine fishes are commonly consumed for its nutritional benefits' and thus lead to transfer toxic metals into the food chain. Harpodon nehereus is a common and local fish from west coast of Maharashtra with high consumption rate among local population. Fish organs particularly liver being major site of detoxification shows structural alterations on exposure to pollution stress from their surrounding environment. Histopathological examination provides an indication of organ impairment to evaluate the health status of selected fish and the degree of pollution in marine environment. The present research effort was done to evaluate the concentration of heavy metals and to study histopathological alterations in liver tissues of largely consumed fish Harpodon nehereus collected from Sassoon dock, west Coast of Maharashtra, India. The research was carried out during the post-monsoon season of the year. High accumulation of lead $(11.8 \pm 8.34 \mathrm{mg} / \mathrm{kg})$, copper $(20.46 \pm 11.06 \mathrm{mg} / \mathrm{kg})$ and Zinc $(286.26 \pm 114.5 \mathrm{mg} / \mathrm{kg})$ were observed in liver tissues. Further histopathological study of present investigation reveals heavy damages in liver tissues of Harpodon nehereus representing that the selected fish is under high threat of pollution stress.
\end{abstract}

\section{KEYWORDS: Harpodon nehereus, Heavy metals, histopathological alterations}

\section{INTRODUCTION}

Fish acts as a definite indicator of pollution and plays an important role in determining the pollution stress in the marine ecosystem. Harpodon nehereus is a most consumable fish from west coast of Maharashtra and offers great source of nutrition to the consumers. Sassoon dock is the oldest and well-known fish landing center located in Mumbai from where most of the sea foods are supplied all over the Mumbai region. Heavy metals are discharged into the marine environment through urban discharge, agriculture, mining combustion and industrial sources and can be taken up by aquatic creatures producing a potential source of heavy metal pollution in the aquatic environment (Saleh, E. A. et al, 2014; Akan, J. C. et al, 2012; Bilandzic, N. et al, 2011; Raja, P. et al, 2009; Yılmaz, F. et al, 2007; Demirak, A. et al, 2006). Metropolises like Mumbai due to its utmost population and hugeportion of industries that generates large amount of waste water and the discharge of effluents without proper treatments leads to pollution stress to aquatic organisms. Sea foods particularly fishes are commonly consumed as rich source of nutrition and thus lead to transfer toxic metals into the food chain. Lead is injurious even in trace amounts (Alturiqi A. S. \& Albedair L. A. 2012; Zhang, Z. et al, 2007) and causes hazardous effects in marine biota (Velusamy, A. et al.,2014; Canli, M., \& Atli, G. 2003). Copper and zinc plays an essential role in metabolic activities of an organism thus acts as an essential metal (Amani S. A. \& Lamia A. A 2012; Bhupander kumar et al 2012; P. Sivaperumal et al, 2007). However increase in the concentration of these essential metals beyond their maximum permissible limits is highly toxic to the consumers and leads to its bioaccumulation in the organs of fishes.
Bioaccumulation of heavy metals leads to cause structural alteration in fish tissues (Imam A.A. mekkawy et al 2013; Mehjbeen Javed and Nazura Usmani, 2013). Heavy metals due to their potential toxicity persuade biochemical alterations in the organs of aquatic organisms (Jalaludeen M.D. et al, 2012). Thus histopathological variations have been broadly used as biomarkers in assessing the health of the fish exposed to pollutants (Marina M.P. C and Claudia B.R. M, 2007; S. Thopan et al, 2003;). Histopathological studies of fishes are progressively being used as indicators of environmental trauma and provide information regarding changes in cellular structure of an organ far earlier than any external sign (Leena Muralidharan, 2014; G.D. Steniford, 2003). One of the great advantages of using histopathological biomarkers in environmental monitoring is that it allows examining specific target organs especially liver involved in vital activities (Marina M.P. C and Claudia B.R. M., 2007). Liver is an organ responsible for detoxification and plays an important role in elimination of toxic substances in the body thus any alteration noticed in liver may indicate pollution stress in their surrounding medium (Hanan S.Gaber et al, 2014).

The present study aims to estimate the level of lead, copper and zinc in liver, tissues of commonly consumed fish Harpadon nehereus collected from famous fish landing center, Sassoon dock, Mumbai during post monsoon season of the year 2017-18. The hazardous levels of selected heavy metals were compared with available certified safety guidelines proposed by Food and Agricultural Organization, 1983 for human consumption (FAO, 1983). Futher the study 
also aims to estimate the structural alterations in liver tissues of selected fish by histopathological examination of liver tissues.

\section{Materials and Methods}

The fishes measuring $26-28 \mathrm{~cm}$ in length and 160-180 grams in weight were collected from Sassoon dock which is the famous fish landing centre, fish whole sale market of Mumbai. The fishes were collected during post monsoon (winter) season of the year 2016 - 2018. The fresh fishes were immediately collected after the landing and brought to the laboratory in ice box for heavy metal estimations and the fishes were immediately dissected at the collection site, kept in fixative and then brought to the laboratory for further processing for Histopathological studies.

\section{A. Heavy metal estimation:}

Fishes were dissected under sterile conditions to remove the liver, tissues. $0.1 \mathrm{~g}$ of Tissue was taken and $4 \mathrm{ml}$ of conc. $\mathrm{HNO}_{3}$ was added to it and heated on hot plate. When it started boiling $1 \mathrm{ml}$ of $\mathrm{HClO}_{4}$ was added and heating continued to destroy theorganic matter from the sample. Samples were then diluted with $5 \mathrm{ml}$ distilled water to make the total volume to $10 \mathrm{ml}$. Concentration of lead, Copper and zinc was evaluated by using ICP-AES (Inductively coupled Plasma Atomic Emission Spectroscopy). Entire experiment including additions of chemicals was performed under sterile condition and the chemicals used for the analysis were of AR grade.

\section{B. Histopathological examination:}

The fresh fishes were immediately collected after the landing, and the fishes were dissected to remove the liver. The excised organs were washed with distilled water and immediately fixed in 10\% neutral buffered formalin and then brought to the laboratory for further processing. Fixed tissues were processed for paraffin embedding technique. Rotary microtome was used to take $5 \mu$ thick sections of the embedded tissues. The selected tissues were stained using haematoxylin and eosin stain (HE). The tissues were fixed by DPX to prepare permanent slides. The extent of damage and structural alterations in the selected tissues were studied by focusing it into different magnification power of compound light microscope and digital photographs were taken to show the specific site of damages observed.

\section{Results and Discussions}

The maximum acceptable levels of lead, copper and Zinc as per FAO, 1983 guidelines was $0.5 \mathrm{mg} / \mathrm{kg}, 30 \mathrm{mg} / \mathrm{kg}$ and $30 \mathrm{mg} / \mathrm{kg}$ respectively and as per WHO, 1989 it was $2 \mathrm{mg} / \mathrm{kg}$, $30 \mathrm{mg} / \mathrm{kg}$ and $100 \mathrm{mg} / \mathrm{kg}$ respectively in fish tissues (table.1). However the level of metals in tissue increases as the pollution level increases in the fish and could go beyond the permissible limitations for human consumption and therefore causes severe health threats (El-Moselhy et al, 2014). According to our investigation the concentration of lead, copper and zinc was found to be $11.8 \pm 8.34 \mathrm{mg} / \mathrm{kg}$, $20.46 \pm 11.06 \mathrm{mg} / \mathrm{kg}$ and $286.26 \pm 114.5 \mathrm{mg} / \mathrm{kg}$ in liver tissues of fish, Harpodon nehereus. All the above mentioned values of selected metals obtained in the present study were above the maximum permissible limits of heavy metals set by FAO 1983 as well as WHO 1989 causing threat to its consumption.
Histopathological studies were conducted to evaluate the extent of metal pollution or stress. The study also offers to identify the effects of irritants, especially chronic ones, in tissues and organs (Drishya M K et al, 2016). Liver act as detoxifying organ and plays a key role in removal of toxic substances in the body. Any alteration observed in liver may indicate bioaccumulation of toxic substances. In the present investigation liver tissues of Harpodon nehereus collected from Sassoon dock, showed severe histopathological alterations. Hepatic tissues showed karyorrhexis, cellular edema, dilation of sinusoidal space and disturbed cordal arrangement as presented in fig. 1. Fig. 2 discloses structural alterations like vacuolated hepatic cells, Pycnosis and fatty degeneration. Liver investigation also showed disintegrated, swollen, ruptured hepatocytes, ruptured central vein and karyolysis (fig 3) during the study period. Severe fatty degeneration, lymphocytic infiltration and focal necrosis were also noticed and presented in fig. 4 .

Essential contribution in the field of environmental pollution and the effects of contaminant exposure on histopathological alteration in organs of fish were also made by many other researchers in their study (Karina Fernandes et al, 2016; Rita Triebskorn et al, 2007; Edith Fanta et al, 2003; Renata Fracacio et al, 2003). Similar annotations were recorded by Mehwish F and Khalid P L in the year 2017 observed histopathological alteration in liver of Ctenopharyngodon idella and observed lymphocytic infilteration and ruptured central vein of liver and indicated it as could be due to contaminant exposure. Hanan S Gaber et al 2014 studied histological changes in marine fish species Solea solea and Mugil cephalus from Bardawil lagoon and observed necrosis, edema and dilation of central vein in liver tissues. Leena Muralidharan, 2014 observed shortened, swollen, ruptured and deformed secondary lamellae of gill, damaged hepatic cells with peripheral pyknosis, ruptured, vacuolated and disintegrated renal cells when the fish Cyprinus carpio were exposed to high concentration of fenthion. Marina M.P.C and Claudia B.R. M, 2007 reported liver tissues with cytoplasmic vacuolation and focal necrosis in their study on Neotropical fish, Prochilodus lineatus. Ashish K Mishra and Banalata Mohanty, 2008 reported vacuolization of hepatocyte with pyknotic nuclei in their study on Channa punctatus. JC Van Dyk et al, 2009 studied histolopathology in tissues of four fish species from Okavango delta, Botswana and showed severe fatty change in liver. Histopathological studies on organs of estuarine fish species were studied by G.D.Steniford et al, 2003 and reported hydrophic vacuolation in biliary epithelium of liver. S. Thopan et al in the year 2003 observed structural alterations where liver cells showed hydropic swelling, in white seabass, Lates calcarifer from commercial fish farm in chonburi, Thailand. All the above mentioned literature work on histopathological alteration in liver tissues of fishes by various researchers indicated structural alteration specifies contamination in the environment and bioaccumulation of toxicants in organ tissues. Supporting all above investigation reports, the structural alterations observed in the liver tissues of fish Harpodon nehereus in the present study could be due to bioaccumulation of heavy metal in liver tissues. The present investigation indicates the health status of fish and its effect on consumers through food chain. 


\section{Figures and Tables}

Table 1: Concentration of lead, copper and zinc in liver tissues of Harpodon nehereus collected from Sassoon dock during post-monsoon (winter) season of the year 2017-18

\begin{tabular}{|c|c|c|c|c|}
\hline \multirow{2}{*}{$\begin{array}{l}\text { Sr. } \\
\text { No. }\end{array}$} & \multirow{2}{*}{$\begin{array}{l}\text { Heavy } \\
\text { metal }\end{array}$} & \multirow{2}{*}{$\begin{array}{c}\text { Concentration } \\
\text { in terms of } \\
\mathrm{mg} / \mathrm{kg}\end{array}$} & \multicolumn{2}{|c|}{$\begin{array}{c}\text { Reference range } \\
\text { (mg/kg) }\end{array}$} \\
\hline & & & $\begin{array}{c}\text { WHO, } \\
1989\end{array}$ & $\begin{array}{l}\text { FAO, } \\
1983\end{array}$ \\
\hline 1 & Lead & $11.8 \pm 8.34$ & 2 & 0.5 \\
\hline 2 & Copper & $20.46 \pm 11.06$ & 30 & 30 \\
\hline 3 & Zinc & $286.26 \pm 114.5$ & 100 & 30 \\
\hline
\end{tabular}

Each metal concentration indicates mean \pm standard deviation

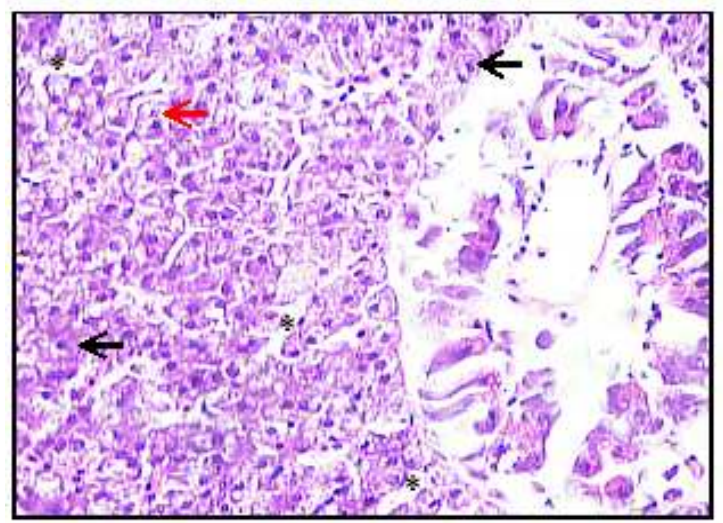

Fig.1. Liver- HE stained, $40 \mathrm{X}$; showing karyorrhexis $(\leftarrow)$; cellular edema $(\leftarrow)$; increase in sinusoidal space $(*)$; disturbed cordal arrangement of hepatic cells.

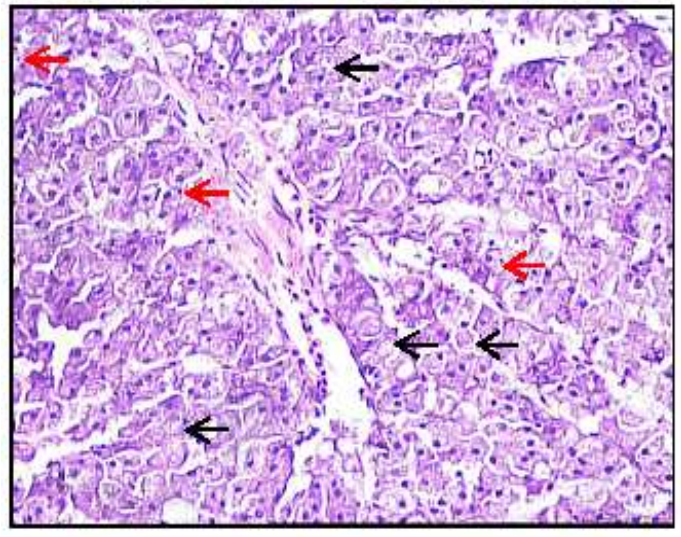

Fig.2. Liver- HE stained, $40 \mathrm{X}$; showing vacuolated hepatocytes $(\leftarrow)$; pyknotic cells $(\leftarrow)$; fatty degeneration

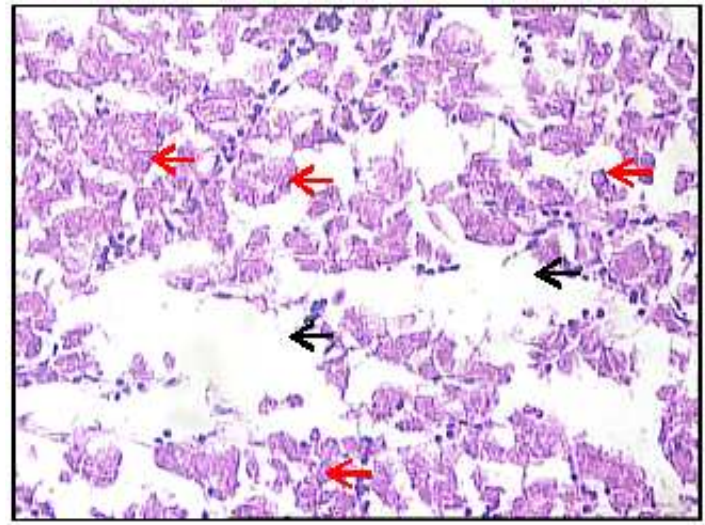

Fig.3. Liver- HE stained, $40 \mathrm{X}$; showing disintegrated, swollen and ruptured hepatic cells; disturbed cordal arrangement; ruptured central vein $(\leftarrow)$; karyolysis $(\leftarrow)$

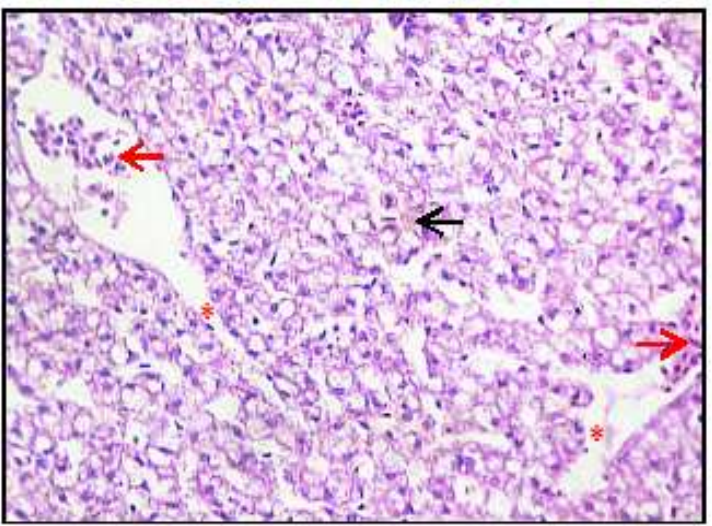

Fig.4. Liver- HE stained, $40 \mathrm{X}$; showing severe fatty change; lymphocytic infiltration $(\leftarrow)$;focal necrosis $(\leftarrow)$; ruptured central vein $\left(^{*}\right)$.

\section{Conclusion}

Increase in the level of heavy metals in our present work indicates that the fish understudy is at high risk of damage due to pollution stress in the marine environment. The concentration of metals in the present work was found to be more than the maximum permissible limits in liver tissues of fish, Harpodon nehereus. Increase in the concentration of metals in liver may possibly be due the process of Bioaccumulation and Bio-magnification. The above results and observations also exhibited structural alterations in liver tissue of Harpodon nehereus that reveals health status of the selected fish. Thus it can be concluded that the fish understudy is at the risk of damage due to pollution stress. Furthermore the structural alterations in selected organ may also lead to imbalance in the physiological mechanisms of the fish. Further studies have to be conducted to keep a continuous check on the extent of pollution stress in the marine ecosystem and its effect on entire food chain.

\section{Acknowledgements}

Authors are thankful to Dr. Usha Mukundan, Principal R. Jhunjhunwala College for providing facilities to carry out this research work successfully and principal of V.K.K. Menon College for constant support and anchoragement. We are grateful to IIT Bombay for providing instrumentation facility for metal analysis. Special thanks to Mr. Santosh Tiwari for helping with slide preparation. We are thankful to Dr. Nafisa Balasinor, Head of the Neuroendocrinology department, NIRRH Parel for providing instrumental facilities to carry out the digital slide photography. Special thanks to Ms. Reshma Gaonkar, Research Scholar, NIRRH, for help rendered during slide photography.

\section{References}

[1] Akan, J. C., Mohmoud, S., Yikala, B. S., \& Ogugbuaja, V. O. (2012). Bioaccumulation of some heavy metals in fish samples from River Benue in Vinikilang, Adamawa State, Nigeria. American Journal of Analytical Chemistry, 3(11), 727.

[2] Alturiqi, A. S., \& Albedair, L. A. (2012). Evaluation of some heavy metals in certain fish, meat and meat products in Saudi Arabian markets. The Egyptian Journal of Aquatic Research, 38(1), 45-49.

[3] Amani S Alturiqi And Lamia A Albedair (2012), Evaluation Of Some Heavy Metals In Certain Fish, Meat And Meat Products In Saudi Arabian Markets. Egyptian Journal Of Aquatic Research, 38, 45-49 
[4] Ashish K. Mishra, Banalata Mohanty (2008). Acute toxicity impacts of hexavalent chromium on behavior and histopathology of gill, kidney and liver of the freshwater fish, Channa punctatus (Bloch). Environmental Toxicology and Pharmacology, 26(2), $136-141$

[5] Bhupander Kumar (2012), Distribution Of Heavy Metals In Valuable Coastal Fishes From North East Coast Of India. Turkish Journal Of Fisheries And Aquatic Sciences, 12, 81-88

[6] Bilandžić, N., Đokić, M., \& Sedak, M. (2011). Metal content determination in four fish species from the Adriatic Sea. Food Chemistry, 124(3), 1005-1010.

[7] Canli, M., \& Atli, G. (2003). The relationships between heavy metal $(\mathrm{Cd}, \mathrm{Cr}, \mathrm{Cu}, \mathrm{Fe}, \mathrm{Pb}, \mathrm{Zn})$ levels and the size of six Mediterranean fish species. Environmental pollution, 121(1), 129-136.

[8] Demirak, A., Yilmaz, F., Tuna, A. L., \& Ozdemir, N. (2006). Heavy metals in water, sediment and tissues of Leuciscus cephalus from a stream in southwestern Turkey. Chemosphere, 63(9), 1451-1458.

[9] Drishya M K, Binu Kumari S, Mohan Kumar M, Ambikadevi AP and Aswin B (2016). Histopathological changes in the gills of fresh water fish, Catla catla exposed to electroplating effluent. International Journal of Fisheries and Aquatic Studies, 4(5), 13-16

[10] Edith Fanta, Flavia Sant'Anna Rios, Silvia Romao, Ana Cristina Casagrande Vianna and Sandra Freiberger (2003). Histopathology of the fish Corydoras paleatus contaminated with sublethal levels relof organophosphorus in water and food. Ecotoxicology and environmental safety, 54, 119-130.

[11] El-Moselhy, K. M., Othman, A. I., El-Azem, H. A., \& ElMetwally, M. E. A. (2014). Bioaccumulation of heavy metals in some tissues of fish in the Red Sea, Egypt. Egyptian Journal of Basic and Applied Sciences, 1(2), 97105.

[12] FAO (1983). Compilation of legal limits for hazardous substance in fishand fishery products (Food and agricultural organization). FAO fishery circular, No. 464, pp. 5-100.

[13] G. D. Stentiford, M. Longshaw, B. P. Lyons, G. Jones, M. Green, and S. W. Feist (2003). Histopathological biomarkers in estuarine fish species for the assessment of biological effects of contaminants. Marine Environmental Research, 55(2), 137-159.

[14] Hanan S Gaber, Seham A Ibrahim, Midhat A El-Kasheif and Fawzia A El-Ghamadi. (2014). Comparison of Tissue Lesions in Two species of Marine Fish (Solea solea and Mugil cephalus) Inhabiting Bardawil Lagoon. Research Journal of Pharmaceutical, Biological and Chemical Sciences (RJPBCS), 5(5), 62-74.

[15] Imam A.A. Mekkawy, Usama M. Mahmoud, Ekbal T. Wassif and Mervat Naguib (2013). Effects Of Cadmium On Some Histopathological And Histochemical Characteristics Of The Kidney And Gills Tissues Of Oreochromis niloticus (Linnaeus, 1758) Dietary Supplemented With Tomato Paste And Vitamin E. Journal Of Fisheries And Aquatic Science, 8(5), 553-580.
[16] Jalaludeen M.D., Arunachalam M., Raja M., Nandagopal.S., Showket Ahmad Bhat, Sundar S., Palanimuthu D. (2012). Histopathology of the gill, liver and kidney tissues of the fresh water fish Tilapia mossambica exposed to cadmium sulphate. International Journal of Advanced Biological research., 2(4), 572-578.

[17] JC van Dyk, MJ Marchand, NJ Smit and GM Pieterse (2009). A histology-based fish health assessment of four commercially and ecologically important species from the Okavango Delta panhandle, Botswana. African Journal of Aquatic Science, 34(3), 273-282

[18] Karina Fernandes Oliveira Rezende, Gabriel Marcelino da Silva Neto, Joana Mona e Pinto, Ligia Maria Salvo, Divinomar Severino, Juliana Cristina Teixeira de Moraes and Jose Roberto Machado Cunha da Silva (2016). Hepatic Parameters of Marine Fish Rachycentron Canadum (Linnaeus, 1766) Exposed To Sub-Lethal Concentrations Of Water-Soluble Fraction Of Petroleum. Journal of Marine Biology and Oceanography, 5(2), 1-6.

[19] Leena Muralidharan (2014). Histopathological studies on Carp (Cyprinus carpio) exposed to fention. International Journal of Advanced research., Vol.2, 1126.

[20] Marina M.P. Camargo and Claudia B.R. Martinez (2007). Histopathology of Gills, Kidney, Liver of a Neotropical fish caged in an urban stream. Neotropical Ichthyology, 5(3), 327-336.

[21] Mehjbeen Javed and Nazura Usmani (2013), Assessment of heavy metal ( $\mathrm{Cu}, \mathrm{Ni}, \mathrm{Fe}, \mathrm{Co}, \mathrm{Mn}, \mathrm{Cr}, \mathrm{Zn}$ ) pollution in effluent dominated rivulet water and their effect on glycogen metabolism and histology of Mastacembelus armatus. SpringerPlus, 2(390), 1-13

[22] Mehwish Faheem and Khalid Parvez Lone (2017). Oxidative stress and histopathologic biomarkers of exposure to bisphenol-A in the freshwater fish, Ctenopharyngodon idella. Brazilian Journal of Pharmaceutical Sciences, 53(3), 1-9.

[23] P. Sivaperumal, T. V. Sankar, \& P. V. Nair (2007). Heavy metal concentrations in fish, shellfish and fish products from internal markets of India vis-a-vis international standards. Food chemistry, 102(3), 612-620.

[24] Raja, P., Veerasingam, S., Suresh, G., Marichamy, G., \& Venkatachalapathy, R. (2009). Heavy metals concentration in four commercially valuable marine edible fish species from Parangipettai Coast, South East Coast of India. International Journal of Animal and Veterinary Advances, 1(1), 10-14.

[25] Renata Fracacio, Nelsy Fenerich Verani, Evaldo Luiz Gaeta Espindola, Odete Rocha, Odila Rigolin-Sa and Cassio Arilson Andrade (2003). Alterations On Growth And Gill Morphology Of Danio Rerio (Pisces, Ciprinidae) Exposed To The Toxic Sediments. Brazilian Archives of Biology and Technology, 46(4), 685-695.

[26] Rita Triebskorn, Ilie Telcean, Heidi Casper, Anna Farkas, Cristina Sandu, Gheorghe Stan, Ovidiu Colarescu, Tiberiu Dori and Heinz-R. Kohler (2008). Monitoring pollution in River Mureş, Romania, part II: Metal accumulation and histopathology in fish. Environ Monit Assess, 141: 177-188 
[27] S. Thophon, M. Kruatrachue, E. S. Upatham, P. Pokethitiyook, S. Sahaphong, \& S. Jaritkhuan (2003). Histopathological alterations of white seabass, Lates calcarifer, in acute and subchronic cadmium exposure. Environmental Pollution, 121(3), 307-320.

[28] Saleh, E. A., Sadek, K. M., \& Ghorbal, S. H. (2014). Bioestimation of selected heavy metals in shellfish and their surrounding environmental media. World Academy of Science, Engineering and Technology, International Journal of Bioengineering and Life Sciences, 1(11).

[29] Velusamy, A., Kumar, P. S., Ram, A., \& Chinnadurai, S. (2014). Bioaccumulation of heavy metals in commercially important marine fishes from Mumbai Harbor, India. Marine Pollution Bulletin, 81(1), 218-224.

[30] Yılmaz, F., Özdemir, N., Demirak, A., \& Tuna, A. L. (2007). Heavy metal levels in two fish species Leuciscus cephalus and Lepomis gibbosus. Food Chemistry, 100(2), 830-835.

[31] Zhang, Z., He, L., Li, J., \& Wu, Z. B. (2007). Analysis of heavy metals of muscle and intestine tissue in fish-in Banan section of Chongqing from three gorges reservoir, China. Polish Journal of Environmental Studies, 16(6), 949. 